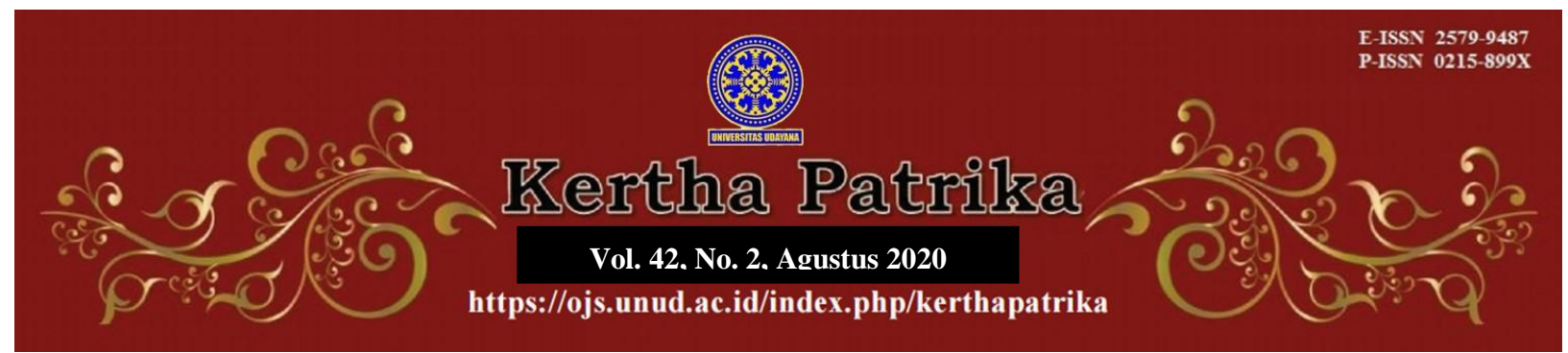

\title{
Model Pengawasan Penggunaan Pinjaman Luar Negeri : Studi World Bank dan IMF di Indonesia
}

\section{Herman Suryokumoro1, Sukarmi ${ }^{2}$, Hikmatul Ula ${ }^{3}$}

\author{
${ }^{1}$ Fakultas Hukum Universitas Brawijaya, E-mail: hermans-fh@ub.ac.id \\ ${ }^{2}$ Fakultas Hukum Universitas Brawijaya, E-mail: sukarmi08@yahoo.com \\ ${ }^{3}$ Fakultas Hukum Universitas Brawijaya, E-mail: hikmah_ula@ub.ac.id
}

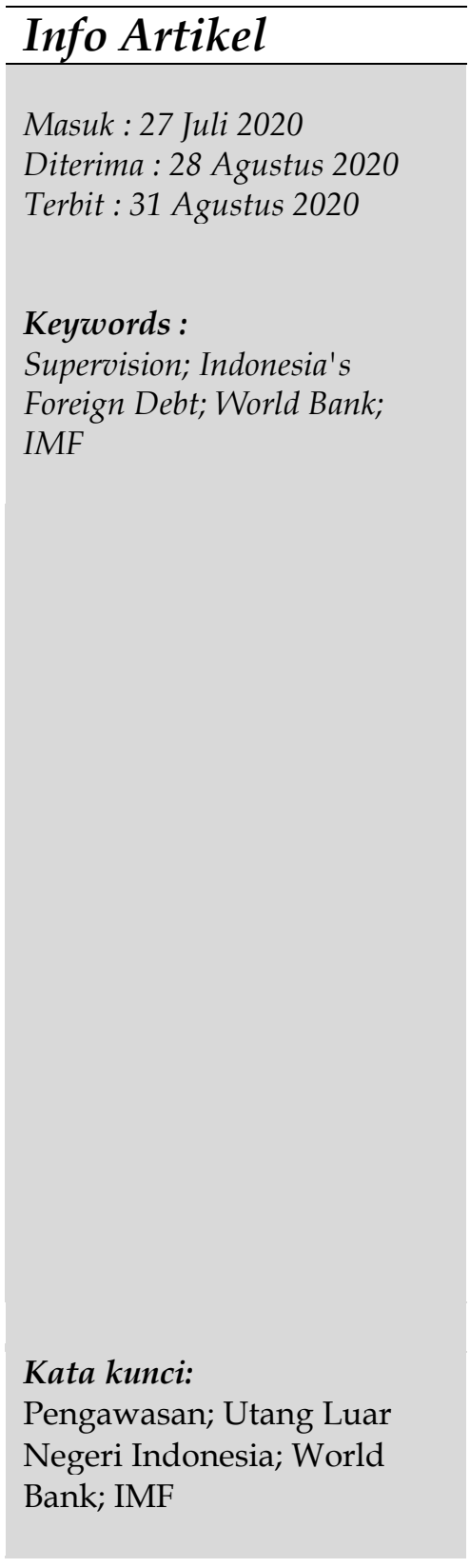

\begin{abstract}
The presence of international debts in the era of economic globalization is an inevitability. The provision of aid by international loan-providing institutions such as the World Bank is very much needed to finance development, especially for developing countries. Using the normative research method and the conceptual approach, this research analyzes the urgency of supervision of international debts and to describe the construction of supervision of international debts, both internally and externally. There are three important reasons why the supervision of the usage of international loans is quite necessary. First, this ensures that the provision of the loans does not have political tendencies that may intervene with state policies; second, this makes sure that the loans are utilized for their intended purposes and targets; and third, this ensures that no fraud or corrupt practices occur in the usage of international loans. The construction of the model of supervision of the usage of international loans can be seen from two aspects. The first aspect is an internal supervision model by government agencies as the users of the loans at the pre-loan agreement stage with substantive procedural supervision, and supervision of loan agreement execution to ensure that it is in line with the goals and is not corrupted. This supervision is carried out by State (law enforcement) institutions or independent institutions. The second is an external supervision model by the international loan-providing institutions (World Bank and International Monetary Fund/IMF) with the mechanisms in integrity institutions as well as investigation and the imposing of sanctions by the Suspension and Debarment Officer (SDO) and the World Bank Group Sanctions Board.
\end{abstract}

\footnotetext{
Abstrak

Adanya utang luar negeri dalam era globalisasi ekonomi adalah sebuah keniscayaan. Pemberian bantuan oleh lembaga pemberi pinjaman internasional seperti World Bank sangat dibutuhkan untuk membiayai pembangunan, khususnya bagi negara-negara berkembang. Dengan
} 


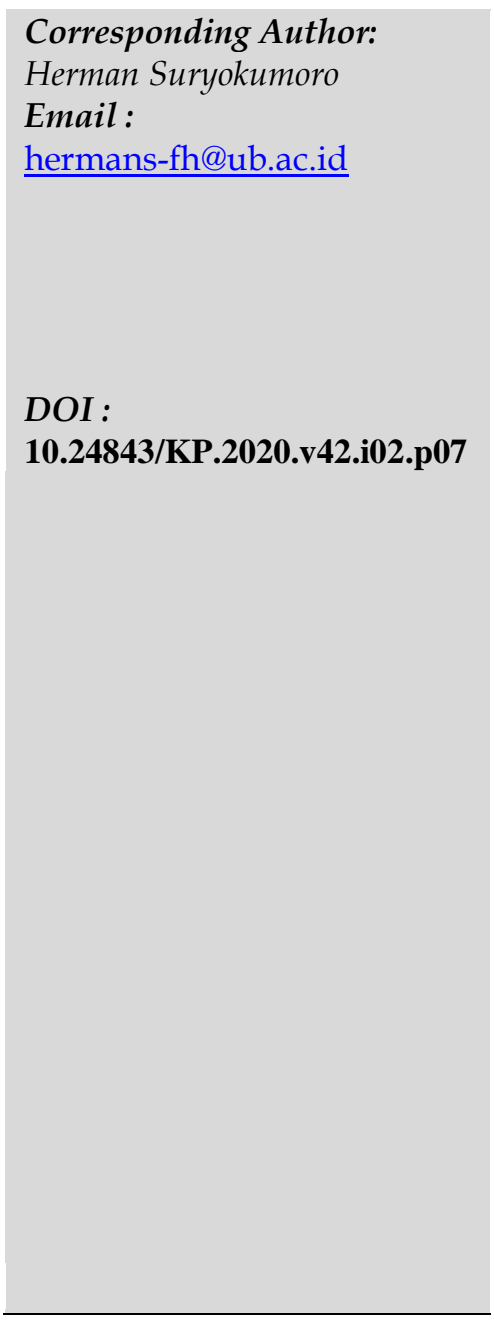

\begin{abstract}
menggunakan metode penelitian normatif dan pendekatan konseptual, penelitian ini bertujuan untuk menganalisis urgensi pengawasan utang luar negeri dan menggambarkan konstruksi pengawasan utang luar negeri baik secara internal maupun eksternal. Penelitian ini mengungkap tiga alasan penting pengawasan terhadap penggunaan utang luar negeri sangat diperlukan. Pertama untuk menjamin tidak ada tendensi politik dari pemberian pinjaman tersebut yang dapat mengintervensi kebijakan Negara, kedua, memastikan utang tersebut digunakan sebagaimana mestinya sesuai dengan tujuan dan tepat sasaran, dan ketiga untuk menjamin tidak ada penyelewengan atau praktik-praktik korupsi dalam penggunaan utang luar negeri. Konstruksi model pengawasan terhadap penggunaan pinjaman luar negeri dapat dilihat dari dua aspek: pertama, aspek internal adalah model pengawasan oleh lembaga pemerintah sebagai pengguna pinjaman- yaitu pada tahap pra perjanjian utang dengan pengawasan substantive procedural dan pengawasan pelaksanaan perjanjian utang agar sesuai dengan tujuan dan tidak dikorupsi. Pengawasan ini dilakukan oleh lembaga Negara (penegak hukum) maupun lembaga independen. Kedua, aspek eksternal adalah model pengawasan oleh lembaga pemberi pinjaman internasional (World Bank dan International Monetary Fund/IMF) yaitu melalui mekanisme lembaga integritas dan penyelidikan dan pemberian sanksi oleh Suspension and Debarment Officer (SDO) dan World Bank Group Sanctions Board.
\end{abstract}

\title{
1. Pendahuluan
}

Hingga Mei 2018 Bank Indonesia mencatat jumlah utang/pinjaman luar negeri Indonesia mencapai USD358,6 milliar atau setara dengan Rp 5.127,98 triliun (kurs Rp 14.300) tumbuh 6,8\% dibandingkan periode bulan sebelumnya. ${ }^{1}$ Berdasarkan catatan Direktorat Jenderal Pengelolaan Pembiayaan dan Risiko (DJPPR) Kementerian Keuangan (Kemenkeu), beberapa utang luar negeri tersebut jatuh tempo pada tahun 2018 dan 2019. Dalam rincian DJPPR, pada 2018 utang jatuh tempo mencapai Rp 390 triliun dan pada tahun 2019 sekitar Rp 420 triliun. $^{2}$ Pada tahun 2020 jumlah utang luar negeri Indonesia melonjak naik akibat pandemi Covid-19. Bank Indonesia mencatat hingga April 2020

\footnotetext{
${ }^{1}$ Laucereno, S.F. (2018). Utang Luar Negeri RI Naik Jadi Rp 5.127 Triliun. Available from: https://finance.detik.com/moneter/d-4118091/utang-luar-negeri-ri-naik-jadi-rp-5127-triliun, (diakses 6 Juli 2020) 2 Adventa, E. (2017). Utang Jatuh Tempo RI di 2018-2019 Mencapai Rp 810 Triliun. Available from: https://ekonomi.kompas.com/read/2017/07/04/110000426/utang.jatuh.tempo.ri.di.20182019.mencapai.rp.810.triliun. (Diakses 6 Juli 2020)
} 
utang luar negeri mencapai Rp. 824,12 triliun. ${ }^{3}$ Hal ini tentu sangat menghawatirkan melihat kondisi perekonomian Indonesia yang semakin terpuruk karena anjloknya nilai tukar rupiah.

Peraturan Pemerintah Nomor 10 Tahun 2011 tentang Tata Cara Pengadaan Pinjaman Luar Negeri dan Penerimaan Hibah (selanjutnya, PP 10/2011) menyebutkan bahwa utang luar negeri digunakan untuk membiayai defisit APBN; membiayai kegiatan prioritas kementerian/lembaga; mengelola portofolio utang; diteruspinjamkan kepada pemerintah daerah; diteruspinjamkan kepada BUMN; dan/atau dihibahkan kepada pemerintah daerah. ${ }^{4}$ Mengingat besarnya utang luar negeri yang dimiliki oleh pemerintah perlu adanya pengawasan terhadap penggunaannya, sehubungan dengan adanya potensi korupsi dalam penggunaan pinjaman/utang tersebut. Tentang pengawasan, PP 10/2011 menyebutkan bahwa pengawasan terhadap pinjaman luar negeri dapat dilakukan secara internal dan eksternal ${ }^{5}$ tetapi tidak mengatur lebih lanjut bagaimana mekanisme pengawasan tersebut.

Pada mulanya kebijakan pinjaman/utang luar negeri bertujuan untuk membantu perekonomian suatu negara, selain itu pemberian pinjaman juga bermotif ekonomi. ${ }^{6}$ Dalam perkembangannya pemberian pinjaman/utang luar negeri juga didasarkan pada aspek good governance atau asas-asas umum pemerintahan yang baik. Artinya, lembaga donor atau kreditor tidak akan memberikan bantuan, pinjaman/utang kepada negara yang tidak menerapkan good governance dalam pemerintahannya. ${ }^{7}$

Masuknya prinsip good governance sebagai salah satu persyaratan bertujuan agar bantuan, pinjaman/utang yang diberikan dapat dikelola dengan baik dan tepat sasaran. Persyaratan ini juga dimaksudkan sebagai sarana pengawasan oleh lembaga pemberi pinjaman/utang, sebagaimana yang telah

\footnotetext{
3 Fauzia, M. (2020). Hingga April 2020, Utang Pemerintah Capai Rp. 5.172,48 Triliun. Availble from: dari: https://money.kompas.com/read/2020/05/21/081100326/hingga-april-2020-utang-pemerintah-capai-rp-5.172-48triliun. (Diakses 6 Juli 2020)

4 Pasal 7 Peraturan Pemerintah Nomor 10 Tahun 2011 tentang Tata Cara Pengadaan Pinjaman Luar Negeri dan Penerimaan Hibah

5 Pasal 81 Peraturan Pemerintah Nomor 10 Tahun 2011 tentang Tata Cara Pengadaan Pinjaman Luar Negeri dan Penerimaan Hibah

${ }^{6}$ Atmadja, A. S. (2000). Utang Luar Negeri Pemerintah Indonesia: Perkembangan dan Dampaknya, Jurnal Akuntansi dan Keuangan, 2 (1), 83-94. doi:10.9744/jak.2.1.pp.\%2083-94, h. 90.

${ }^{7}$ Qureshi, A. H. (1999). International Economic Law. Manchaster: Sweet and Maxwell, h.27.
} 
dilakukan oleh World Bank dalam kasus Siemens ${ }^{8}$, proyek pengadaan buku ${ }^{9}$, dan proyek infrastruktur untuk daerah Indonesia timur ${ }^{10}$.
Dalam ketiga
kasus
tersebut
ditemukan
praktik-praktik kecurangan/korupsi yang dilakukan oleh penerima bantuan/dana World Bank. Melalui Departemen Integritas Kelembagaan (Departement of Institution Integrity) World Bank melakukan penyelidikan atas adanya dugaan korupsi pada setiap proyek yang didanainya dan selanjutnya akan dijatuhkan sanksi.

Pertanyaan selanjutnya adalah sejauhmana Departemen Integritas tersebut melakukan pengawasan? Apakah sanksi yang diberikan cukup efektif? Dan apakah model pengawasan World Bank tersebut dapat diterapkan dalam pinjaman dari IMF? Beberapa pertanyaan tersebut membutuhkan telaah lebih lanjut.

Setidaknya ada dua hal penting yang harus diperhatikan dalam kebijakan utang luar negeri tersebut, pertama bagaimana penggunaan utang/pinjaman tersebut, dari mana dan untuk apa utang tersebut digunakan. Kedua, bagaimana pengawasan terhadap penggunaan utang tersebut, apakah penggunaan utang tersebut sudah sesuai, bagaimana jika ada pelanggaran atau tidak tepat dalam pelaksanaannya, apakah ada mekanisme sanksi dari lembaga pemberi utang/pinjaman tersebut.

World Bank dan IMF memiliki karakteristik yang berbeda dari segi pinjaman yang diberikan, World Bank dengan pinjaman/utang kegiatan dan IMF dengan pinjaman/utang tunai. ${ }^{11}$ Pengawasan atas penggunaan penggunaan pinjaman tersebut tentu membutuhkan treatment yang berbeda pula. Untuk itu perlu dilakukan sebuah penelitian untuk mengetahui dan menganalisis model pengawasan pengunaan pinjaman luar negeri oleh lembaga pemberi pinjaman (World Bank dan IMF).

\section{Metode Penelitian}

Penelitian ini menggunakan metode normatif atau doktrinal dengan pendekatan konseptual. ${ }^{12}$ Sebagai bahan hukum primer penelitian ini adalah Article of Agreement of IBRD; Article of Agreement of IMF; dan Peraturan Pemerintah RI Nomor 10 Tahun 2011 tentang Tata Cara Pengadaan Pinjaman Luar Negeri dan Penerimaan Hibah sebagai

\footnotetext{
8 The World Bank. Siemens to Pay $\$ 100$ Million to Fight Fraud and Corruption as Part of World Bank Group Settlement. Available from: https://www.worldbank.org/en/news/press-release/2009/07/02/siemens-pay-millionfight-fraud-corruption-part-world-bank-group-settlement. (Diakses 6 Juli 2020).

9 Bank Dunia mengumumkan daftar hitam terhadap 10 individu dan 26 perusahaan karena praktek curang dan korupsi sehubungan dengan "Proyek Pengembangan Buku dan Bacaan" (Book and Reading Development Project, BRDP) di Indonesia senilai \$52,232,000 yang didanai oleh Bank Dunia. Perusahaanperusahaan ini tidak berhak lagi menerima kontrak baru apa pun yang didanai oleh Bank Dunia selama periode mereka ada dalam daftar hitam.

Lihat: Bank Dunia Memberikan Sanksi Kepada Penerbit Indonesia dalam Proyek Pengembangan Buku dan Bacaan, Available from: https://materikuliahfhunibraw.files.wordpress.com/2009/09/bank-dunia-memberikan-sanksikepada-penerbit-indonesia-dalam-proyek-pengembangan-buku-dan-bacaan.pdf (Diakses 6 Juli 2020)

10 Lihat: Bank Dunia Menemukan Tindak Korupsi dalam Proyek Jalan dan Sependapat dengan Pemerintah mengenai Rencana Tindakan Lanjutan untuk meningkatkan Pengadaan dan untuk Penanganan Kesalahan dalam Proyek, Available from: wwww.worldbank.org. (Diakses 7 Juli 2020)

11 International Monetary Fund. (2020). The IMF and The World Bank. Avalable From:

https://www.imf.org/en/About/Factsheets/Sheets/2016/07/27/15/31/IMF-World-Bank. Diakses 19 Agustus 2020

${ }^{12}$ Ibrahim, J. (2008). Teori dan Metodologi Penelitian Hukum Normatif. Malang: Bayu Media. h.10.
} 
acuan utama pengawasan utang luar negeri. Bahan hukum tersebut dianalisis dengan teknik deskriptif analitis dengan sehingga diketahui model pengawasan utang luar negeri.

\section{Hasil dan Pembahasan}

\subsection{Urgensi Pengawasan Penggunaan Utang/Pinjaman Luar Negeri oleh Lembaga Pemberi Pinjaman}

Utang/pinjaman luar negeri menjadi salah satu komponen penting dalam pembiayaan Negara. Selain pendapatan dari pajak dan hasil pengelolaan sumber daya, utang perupakan jalan pintas Negara untuk mendapat dana guna membiayai pembanguan, utang merupakan bagian dari kebijakan Anggaran Pendapatan dan Belanja Negara (APBN) yang menjadi bagian dari kebijakan pengelolaan ekonomi secara keseluruhan. ${ }^{13}$ Pengelolaan ekonomi bertujuan untuk menciptakan kemakmuran rakyat dalam bentuk: penciptaan kesempatan kerja, mengurangi kemiskinan, menguatkan pertumbuhan ekonomi, serta menciptakan keamanan. ${ }^{14}$

Pembiayaan APBN melalui utang merupakan bagian dari pengelolaan keuangan Negara yang lazim dilakukan. Utang merupakan konsekuensi dari postur APBN yang mengalami defisit, dimana pendapatan Negara lebih kecil dari pada belanja Negara. Utang dapat menjadi instrument utama pembiayaan APBN untuk menutup defisit, dan untuk membayar kembali utang yang jatuh tempo (dept refinancing). ${ }^{15}$

Tujuan jangka panjang utang adalah untuk mengamankan pembiayaan APBN melalui utang dengan biaya minimal pada tingkat risiko terkendali; dan mendukung upaya untuk menciptakan pasar Surat Berharga Negara (SBN) yang dalam, aktif, dan likuid. Sedangkan tujuan jangka pendek utang adalah untuk memastikan tersedianya dana untuk menutupi defisit dan pembayaran kewajiban pokok utang secara tepat waktu dan efisien. ${ }^{16}$ Dengan demikian peran dan tujuan adanya utang sangat penting bagi stabilitas keuangan negara sehingga harus dilakukan pengawasan.

Pengawasan dapat diartikan sebagai penjagaan atau "kontrol". Pengawasan menentukan apa yang telah dicapai, mengevaluasi dan menerapkan tindakan korektif, jika perlu, memastikan hasil yang sesuai dengan rencana. ${ }^{17}$ Lebih lanjut titik berat pengawasan adalah suatu usaha untuk menjamin agar pelaksanaan suatu tugas dapat

\footnotetext{
${ }^{13}$ Aziz, A. (2011). Analisis Urgensitas Pinjaman Luar Negeri Indonesia dalam Rangka Pembiayaan Defisit APBN. Kajian Ekonomi dan Keuangan. 15 (1), 1-34. DOI:10.31685/kek.v15i1.78, h.3.

14 Ibid, h.4.

15 Panjaitan, Y. Y. Winarno, M. \& Ramiayu, D. D. (2019). Perkembangan Utang Pemerintah Pusat. Jakarta: Pusat Kajian Anggaran Badan Keahlian DPR-RI. p 1, Available from: http://berkas.dpr.go.id/puskajianggaran/referensi-apbn/public-file/referensi-apbn-public-19.pdf, $\quad$ (Diakses 10 Agustus 2020)

16 Profil Utang Pemerintah Pusat, Pinjaman dan Surat Berharga Negara. (2015). Kementerian Keuangan Republik Indonesia Direktorat Jendral Pengelolaan Pembiayaan dan Resiko. Available from: https://www.djppr.kemenkeu.go.id/uploads/files/dmodata/BSPUPP\%20(Govt\%20Debt\%20Profile)\%20edisi\%20Des \%202015.pdf, (Diakses 6 Juli 2020)

17 Muchsan. (1992). Sistem Pengawasan terhadap perbuatan Aparat Pemerintah dan Peradilan Tata Usaha Negara di Indonesia. Yogyakarta: Liberty, h. 37.
} 
sesuai dengan yang direncanakan, baik pada saat proses suatu kegiatan sedang berjalan, maupun setelah akhir proses kegiatan dilaksanakan..$^{18}$

Pengawasan juga bertalian dengan arahan (directive). ${ }^{19}$ Arahan tersebut sebagai bentuk upaya untuk menghindari terjadinya kekeliruan-kekeliruan, baik sengaja maupun tidak disengaja, sebagai usaha preventif, maupun sebagai usaha represif.20Kegiatan pengawasan ditujukan semata-mata hanya agar pemerintah menjalankan tugas dan wewenangnya sesuai peraturan yang ada. ${ }^{21}$

Secara teoritis, aliran Neo-Klasik menyatakan bahwa utang/pinjaman luar negeri diperlukan bagi pembiayaan pembangunan yaitu untuk menutup gap saving akibat domestic saving yang tidak mencukupi untuk pembiayaan pembangunan. ${ }^{22}$ Saving gap dapat ditutup dengan cara debt creating flow (DCF) dan non debt creating flow (NDCF). DCF dapat berupa utang bilateral maupun multilateral, sedang NDCF berupa penanaman dan penyertaan modal seperti Foreign Direct Investment (FDI), short term capital dan long term capital. ${ }^{23}$ Teori lain menjelaskan bahwa utang berfungsi sebagai gap filling yaitu mengisi gap akibat defisit neraca berjalan, dalam hal ini utang berfungsi sebagai modal untuk menyeimbangkan defisit dalam neraca keuangan. ${ }^{24}$

Penjelasan di atas menunjukkan bahwa utang memiliki peran penting dalam pembiayaan negara. Hal ini membuat pengawasan terhadap penggunaan utang tersebut adalah sebuah keharusan. Kegiatan pengawasan ditujukan semata-mata hanya agar pemerintah menjalankan tugas dan wewenangnya sesuai peraturan yang ada. Dengan adanya pengawasan diharapkan mampu untuk (1) menghentikan atau meniadakan kesalahan, penyimpangan penyelewengan dan hambatan, (2) mencegah terulangnya kembali kesalahan, penyimpangan, penyelewengan dan hambatan, (3) mendapatkan cara-cara yang lebih baik untuk mencapai tujuan dalam melaksanakan tugas pokok dan fungsinya secara efektif.

Khusus dalam hal pengawasan penggunaan utang/pinjaman luar negeri Pasal 81 PP 10/2011 menyebutkan bahwa Pengawasan terhadap pelaksanaan dan penggunaan pinjaman luar negeri atau hibah dilakukan oleh instansi pengawas internal dan eksternal sesuai dengan ketentuan perundangundangan. Dengan demikian pengawasan terhadap penggunaan pinjaman luar negeri dapat berasal dari lembaga pemerintah -sebagai pengguna pinjaman- atau dari lembaga pemberi pinjaman (World Bank dan IMF)

Terdapat tiga alasan penting pengawasan terhadap penggunaan utang luar negeri sangat diperlukan. Pertama untuk menjamin tidak ada tendensi politik dari pemberian pinjaman tersebut yang dapat mengintervensi kebijakan Negara, kedua, memastikan utang tersebut digunakan sebagaimana mestinya sesuai dengan tujuan dan tepat sasaran, dan ketiga untuk menjamin

\footnotetext{
${ }^{18}$ Ibid.

19 Manan, B. (2001), Menyongsong Fajar Otonomi Daerah, Yogyakarta: Pusat Studi Fakultas Hukun UII, Yogyakarta, h. 20.

${ }^{20}$ Lotulung, P.E. (1993) Beberapa Sistem tentang Kontrol Segi Hukum terhadap Pemerintah, Bandung: Citra Aditya Bakti, hal. xvi-xvii.

${ }^{21}$ Ibid.

22 Todaro, M. P. (1994). Economic Development. 5th Edition, New York: Longman Publishing. h. 13.

${ }^{23}$ Lin, S. \& Sosin, K. (2003). Foreign Debt and Economic Growth. Economics of Transition and Institutional Change, 9 (3), 635-655. doi: 10.1111/1468-0351.00092. h. 635.

24 James C., (1986) International Economic, New York: John Wiley and Sons, h. 25.
} 
tidak ada penyelewengan atau praktek-praktek korupsi dalam penggunaan utang luar negeri. ${ }^{25}$

1. Tidak ada intervensi

Adanya intervensi asing dalam pemberian utang luar negeri hingga saat ini masih menjadi perdebatan. Pihak-pihak yang kontra terhadap utang/pinjaman luar negeri mendalilkan bahwa independensi Negara akan tereduksi dengan adanya utang, dengan kata lain tidak ada utang yang "bebas nilai" atau bebas dari muatan politik/kepentingan pemberi utang. ${ }^{26}$

Intervensi tersebut dapat dilihat dari syarat dan ketentuan yang tercantum dalam klausula-klausala dalam perjanjian pemberian utang/pinjaman. Dari perjanjian tersebut Negara harus membuat produk-produk hukum atau kebijakan yang sesuai dengan kesepakatan. Misalnya Negara harus membuat Undang Undang Anti Monopoli sebagai konsekuensi perjanjian utang dengan IMF. ${ }^{27}$

Adanya intervensi tersebut telah diantisipasi dalam peraturan, yaitu dalam Pasal 2 PP 10/2011 yang menyebutkan bahwa utang/pinjaman luar negeri dan penerimaan hibah harus memenuhi prinsip: a) transparan; b) akuntabilitas; c) efisien dan efektif; d) kehatihatian; e) tidak disertai ikatan politik; dan f) tidak memiliki muatan yang dapat mengganggu stabilitas nasional.

Namum demikian, adanya intervensi asing dalam kebijakan ekonomi Negara akibat masuknya modal asing -termasuk utang- seolah tidak dapat dihindari. Hal ini berdasarkan pada konsekuensi yang hadir bakibat suatu consensus atau kesepakatan dalam perjanjian, sehingga para pihak wajib menjalankan kesepakatan tersebut, termasuk untuk menyesuaikan kebijakan dan hukum dalam negerinya. ${ }^{28}$

Terkait dengan fungsi pengawasan, untuk mencegah adanya intervensi yang beelebihan dalam kebijakan ekonomi harus dilakukan pengawasan. Pegawasan tersebut dilakukan pada tahap pra pembuatan atau penandatanganan perjanjian. Penelitian terhadap naskah dan substansi perjanjian sehingga tidak menimbulkan kerugian jika perjanjian tersebut terlanjur ditandatangani atau disepakati.

Disamping itu pemerintah juga dapat menggunakan lembaga reservasi terhadap perjanjian yang dinilai tidak menguntungkan atau

\footnotetext{
${ }^{25}$ Article III Section 5 (b) Article of Agreement of International Bank for Reconstruction and Development

${ }^{26}$ Odedokun, M. (2004). Multilateral and Bilateral Loans Versus Grants: Issues and Evidence. The World Economy, 27 (2), 239-263. doi:10.1111/j.1467-9701.2004.00598.x h.230.

27 Bradshaw, Y. W. \& Huang J. (2016). Intensifying Global Dependency: Foreign Debt, Structural Adjustment, and Third World Underdevelopment, The Sociological Quarterly, 32 (3). 321-342. doi: 10.1111/j.1533-8525.1991.tb00162.x, h.325.

${ }_{28}$ Chung, K. (2010). Foreign Debt, Foreign Direct Investment and Volatility. International Economic Journal, 24 (2), 171-196. doi: 10.1080/10168731003649628, h.180.
} 
secara prinsip Negara tidak dapat mengikuti salah satu atau sebagian ketentuan dalam perjanjian tersebut. ${ }^{29}$

2. Penggunaan pinjaman sesuai dengan tujuan

Alasan utama dari adanya utang luar negeri adalah untuk pembiayaan pembangunan, oleh karena itu penggunaan pinjaman luar negeri diperuntukkan seluas-luasnya untuk kepentingan masyarakat sebagaimanya ketentuan Pasal 7 ayat (1) PP 10/2011.

Selain itu, tujuan utang dapat dilihat dari perjanjian utang tersebut, tujuan utang biasanya tidak lepas dari pembiayaan taktis program-program pembangunan. ${ }^{30}$ Terkait dengan pengawasan, dalam hal ini pengawasan dilakukan pada tahap penyaluran dan penggunaan utang sesuai dengan tujuannya. Pengawasan menjamin adanya ketercapaian dan ketepatan dalam penggunaan utang.

3. Tidak ada praktik-praktik korupsi dan pelanggaran hukum lain dalam penggunaan pinjaman

Hingga saat ini masalah korupsi menjadi perhatian serius bagi pemerintah. Korupsi mengancam seluruh aspek pemerintahan terutama dalam hal penggunaan angaran, tidak terkecuali penggunaan utang luar negeri. Menurut Jefrey A Winters, paling tidak sepertiga dari bantuan (pinjaman) Bank Dunia untuk Indonesia bocor di birokrasi Indonesia. Dalam hasil survey Transparancy International terhadap 52 negara, Indonesia menempati peringkat ke-7 dan di antara negara ASEAN, berada pada peringkat pertama. ${ }^{31}$

Di samping itu, Bank Dunia juga pernah memberikan sanksi kepada pemerintah RI karena terbuki melakukan praktek korupsi dalam proyek infrastruktur untuk daerah Indonesia Timur. Dengan demikian pengawasan dilakukan agar dana yang diperoleh dari utang/pinjaman tersebut benar-benar digunakan untuk mebiayai pembangunan dan tidak diselewangkan oleh oknum pejabat atau pihak lain yang berkepentingan.

Terkait dengan masalah korupsi pengawasan tidak hanya dilakukan oleh lembaga pemberi utang/pinjaman tetapi juga oleh hukum positif, yaitu mengoptimalkan peran aparat penegak hukum dan lembaga yang ada misalnya kepolisian, kejaksaan dan Komisi Pemberantasan Korupsi (KPK).

\subsection{Konstruksi Model Pengawasan Penggunaan Utang/Pinjaman Luar Negeri di Indonesia}

\footnotetext{
29 Bakry, A.B. (2001). Beberapa Aspek Reservasi Dalam Perjanjian Internasional. Perspektif, VI (4), 291-304. DOI: 10.30742/ perspektif.v6i4.536, h. 295.

30 Sulistyowati, D. \& Suliswanto, M.S.W. (2015). Pertumbuhan Ekonomi, Indeks PembangunanManusia, Utang Luar Negeri dan Kemiskinan (Kajian Teoritis di Indonesia). Journal of Innovation in Business and Economics. 6 (1), 89-106. DOI: 10.22219/jibe.v6i1.2276.h. 98.

${ }^{31}$ Hamid, E.S. (2000), Perekonomian Indonesia Masalah dan Kebijakan Kontemporer, Yogyakarta: UII Press, h.67.
} 
Merujuk pada ketentuan Pasal 81 PP 10/2011 tentang instansi pengawasan internal dan eksternal terhadap penggunaan pinjaman luar negeri atau hibah, konstruksi model pengawasan terhadap penggunaan pinjaman luar negeri dapat dilihat dari dua aspek: internal yaitu model pengawasan oleh lembaga pemerintah -sebagai pengguna pinjaman-; dan dari aspek eksternal yaitu model pengawasan oleh lembaga pemberi pinjaman (World Bank).

Secara umum konstruksi pengawasan utang luar negeri dapat digambarkan sebagai berikut:

\section{Gambar 1. Konstruksi Pengawasan Utang Luar Negeri}

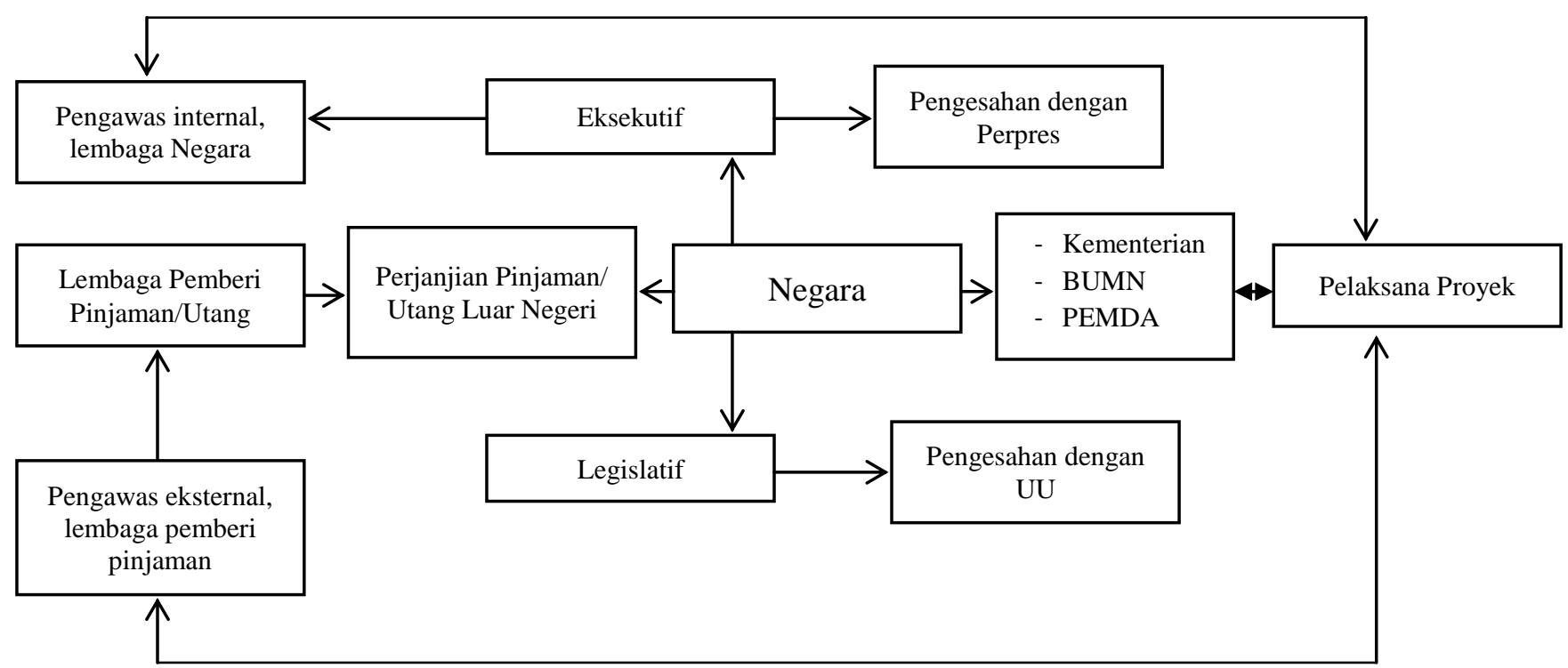

\section{Sumber: Hasil analisis penulis}


Timbulnya utang negeri diawali dengan adanya perjanjian antara Negara atau pemerintah dengan lembaga pemberi pinjaman. ${ }^{32}$ Perjanjian tersebut kemudian disahkan atau ditransformasikan dalam hukum nasional dalam bentuk Undang Undang ${ }^{33}$ atau Peraturan Presiden. ${ }^{34}$ Setelah disahkan sesuai dengan ketentuan tersebut, Negara menggunakan utang tersebut sesuai dengan tujuannya. Pengguna pinjaman dapat pemerintah secara langsung (membiayai defisit APBN), kementerian untuk membiayai program-program kementerian, BUMN, atau Pemerintah Daerah dengan diteruspinjamkan atau dihibahkan oleh pemerintah pusat ${ }^{35}$ dan selanjutnya dilaksanakan oleh penerima/pelaksana proyek.

\subsubsection{Konstruksi Model Pengawasan Internal}

Konstruksi model pengawasan utang luar negeri dapat dlihat dari tahapan atau proses terjadinya utang, yaitu pada tahap pra (sebelum) perjanjian utang dan pada saat pelaksanaan utang. Pada tahap pra (sebelum) terjadinya utang, pengawasan dilakukan terkait dengan prosedur pembuatan perjanjian internasional -tentang utang- dan substansi perjanjian. Konstruksi model pengawasan internal dapat digambarkan sebagai berikut:

\section{Gambar 2. Konstruksi Model Pengawasan Internal}

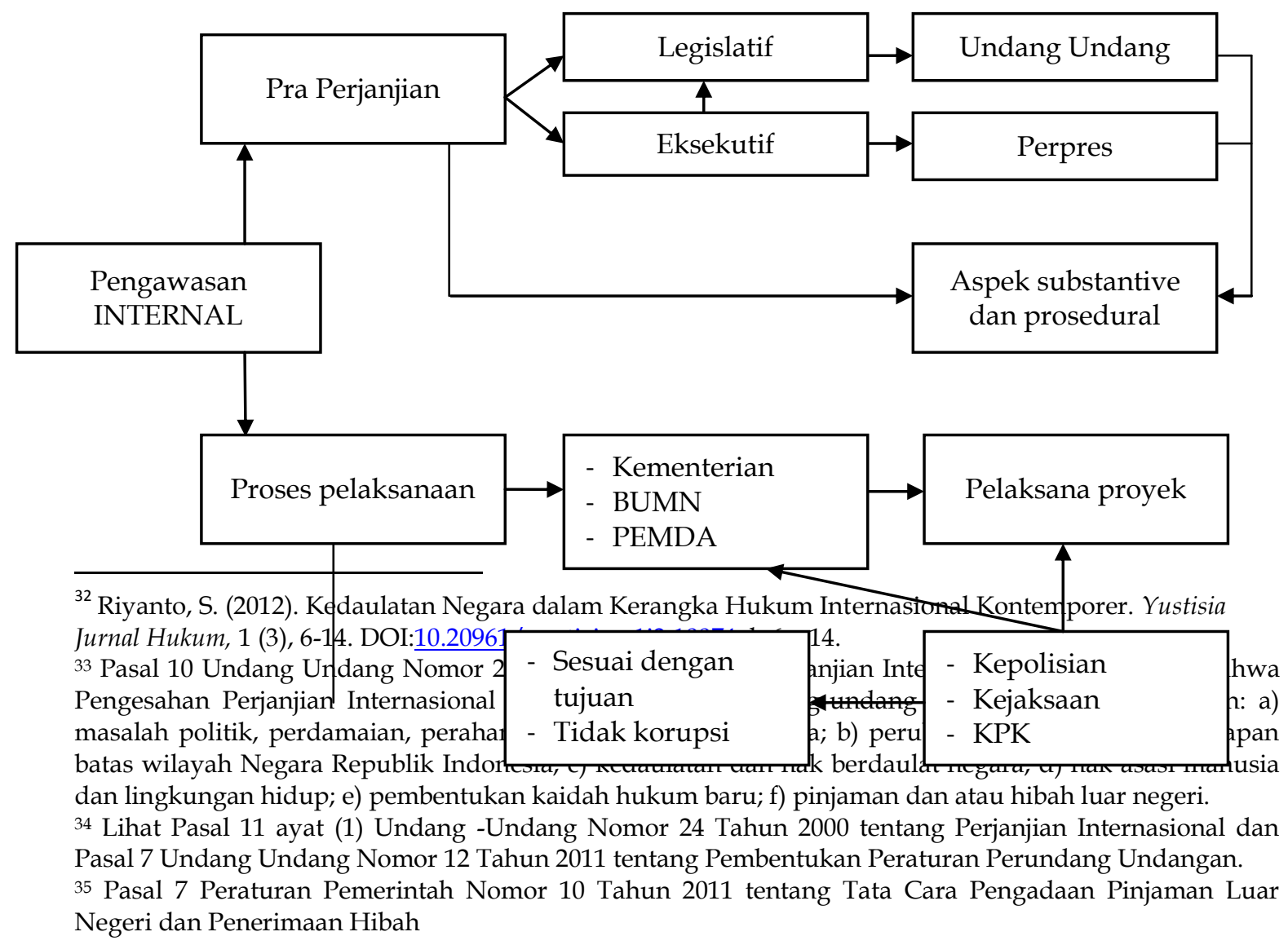




\section{Sumber: Hasil analisis penulis}

Pada tahap pra perjanjian pengawasan dilakukan dengan melihat prosedur formal pembuatan perjanjian apakah telah sesuai dengan ketentuan perundangundangan khususnya Undang Undang Nomor 24 tahun 2000 tentang Perjanjian Internasional (UU 24/2000). Selain itu, pengawasan juga dilakukan dengan meneliti klausula dalam perjanjian utang sebelum ditandatangani atau disahkan apakah telah sesuai dengan landasan filosofis, yuridis dan sosiologis dan untuk mencegah terjadinya kemungkinan adanya upaya intervensi kebijakan atau hal-hal lain yang merugikan Negara.

Pasal 9 ayat (2) UU 24/2000 menyebutkan bahwa Pengesahan perjanjian internasional dilakukan dengan Undang Undang atau Keputusan Presiden. Selanjutnya untuk kriteria perjanjian mana yang pengesahannya dilakukan dengan Undang Undang dan perjanjian mana yang pengesahannya dilakukan dengan Keputusan Presiden Mahkamah Konstitusi berdasarkan Putusan Nomor 13/PUUXVI/2018 menyatakan bahwa untuk perjanjian internasional yang menimbulkan akibat hukum yang luas dan mendasar yang terkait dengan beban/keuangan negara dan/iatau mengharuskan perubahan atau pembentukan undang undang, maka pengesahan perjanjian internasional membutuhkan persetujuan Dewan Perwakilan Rakyat (DPR), dalam hal ini disahkan dengan Undang Undang. ${ }^{36}$

Berdasarkan penjelasan di atas dapat diketahui bahwa pengesahan perjanjian pinjaman/utang luar negeri menggunakan undang undang dengan argumentasi bahwa adanya utang berimplikasi terhadap beban/keuangan negara. Mekanisme pengesahan menggunakan undang-undang melibatkan lembaga eksekutif dan legislatif. Dengan demikian, utang/pinjaman yang diberikan kepada pemerintah oleh lembaga pemberi pinjaman harus memerlukan persetujuan terlebih dahulu dari DPR untuk disahkan menjadi undang undang. Pengawasan dapat dilakukan oleh DPR pada saat mencermati substansi perjanjian utang sebelum disahkan menjadi undang undang.

Pada tahap pelaksanaan utang yang menjadi inti pengawasan adalah pelaksana proyek atau penerima dana utang menjamin tidak ada penyelewengan atau korupsi dan dana tersebut digunakan sesuai dengan maksud dan tujuannya. Pengawasan ini dilakukan oleh lembaga-lembaga Negara yang berwenang yaitu Kepolisian, Kejaksaan, dan KPK, dan juga lembaga independen di luar pemerintah yang dibentuk khusus untuk mengawasi jalannya proyek utang tersebut.

\subsubsection{Konstruksi Model Pengawasan Eksternal}

\footnotetext{
${ }^{36}$ Wuisang, A. (2019). Kewenangan DPR Dalam Ratifikasi Perjanjian Internasional Pasca Terbitnya Putusan Mahkamah Konstitusi No. 13/PUU-XVI/2018. Pakuan Law Review, 5 (2), 121-145. DOI: $10.33751 / . v 5 i 2.1189$. h. 138.
} 
Konstruksi model pegawasan eksternal dilakukan oleh lembaga pemberi pinjaman yaitu World Bank dan IMF.

a. Mekanisme Pengawasan World Bank

Instrument dasar World Bank mengatur tentang ketentuan umum terkait pinjaman dan jaminan serta sistem operasinya. ${ }^{37}$ Tentang pengawasan utang World Bank memiliki lembaga khusus yaitu Integrity Vice Presidency (INT) atau lembaga integritas. Tugas dan wewenang INT adalah melakukan penelitian terhadap laporan adanya pelanggaran penggunaan atau pelaksaan proyek yang didanai World Bank. INT kemudian melanjutkan temuan tersebut kepada lembaga sanksi World Bank. ${ }^{38}$

Evolusi sistem sanksi World Bank telah berkembang sejak tahun 1996, dilanjutkan dengan peninjauan menyeluruh terhadap proses sanksi pada 2002, dan kemudian pelaksanaan perjanjian cross-debarment agreement dengan bank pembangunan multilateral (multilateral development banks/MDBs) lainnya yang mengamanatkan pengakuan terhadap keputusan-keputusan sanksi. ${ }^{39}$ Sistem sanksi World Bank terdiri dari proses ajudikasi dua tingkat. Review tingkat pertama dilakukan oleh Suspensi Bank dan larangan Officer (Bank's Suspension and Debarment Officer/SDO) dan ditingkat kedua review dilakukan oleh Dewan Sanksi Bank Dunia (World Bank Group Sanction Board), sebuah badan pengadilan administratif independen yang berfungsi sebagai pengambil keputusan akhir yang terdiri dari 7 orang hakim eksternal. ${ }^{40}$ Di tingkat pertama, SDO memiliki kewenangan untuk menentukan:

(1) apakah bukti yang diajukan oleh Integrity Vice Presidency (INT) sudah cukup untuk mendukung temuan bahwa responden yang terlibat dalam penipuan, korupsi, pemaksaan, kolusi, atau obstruksi sehubungan dengan proyek yang dibiayai World Bank, atau melanggar syarat dan ketentuan dari Program Pengungkapan Sukarela/ Voluntary Disclosure Program (VDP); ${ }^{41}$ dan

(2) apakah responden harus dihentikan sementara dari penawaran pada kontrak yang dibiayai Bank, sambil menunggu hasil akhir dari proses sanksi.

Selain itu, SDO merekomendasikan sanksi yang akan dikenakan pada responden, yang menjadi efektif di mana responden memilih untuk tidak menantang tuduhan terhadap itu. Jika responden tidak setuju atas tuduhan atau sanksi direkomendasikan SDO, kasus ini dilanjutkan pada Dewan Sanksi. Ada lima sanksi administratif yang mungkin diberikan yaitu: Surat Umum Teguran, daftar hitam, Bersyarat Non-daftar hitam, daftar hitam dengan Bersyarat Rilis, dan Restitusi.

Pada tingkat kedua Dewan Sanksi melakukan review de novo42 penuh dalam setiap kasus. Hal ini tidak terikat dengan rekomendasi SDO. Sidang administrasi dapat

\footnotetext{
37 Article III and IV Article of Agreement of International Bank For Reconstruction and Development

38 Lihat penjelasan singkat mengenai INT pada artikel the World Bank. Integrity Vice Presidency.

Available from https://www.worldbank.org/en/about/unit/integrity-vice-presidency (Diakses 21 Agustus 2020).

39 Pascale, H.D., Ezzeddin, P., \& Swan, C. David. (2016). Suspension and Debarment on the International Stage: Experiences in the World Bank's Sanctions System. Public Procurement Law Review,25 (3). h.63. 40 The World Bank. World Bank Group Sanction Board. Available from https://www.worldbank.org/en/about/unit/sanctions-system/sanctions-board 41 Lihat penjelasan singkat mengenai VDP pada artikel The World Bank. World Bank Launches Voluntary Disclosure Program. Available from https://www.worldbank.org/en/news/pressrelease/2006/08/15/world-bank-launches-voluntary-disclosure-program

42 Standar review dimana pengadilan banding meninjau kembali keputusan pengadilan yang lebih rendah seolah-olah pengadilan yang lebih rendah belum memberikan keputusan. Pengadilan banding memandang kasus tersebut seolah-olah dibawa ke pengadilan untuk pertama kalinya, sehingga review
} 
diadakan oleh Dewan Sanksi baik atas permintaan pihak atau pada kebijaksanaan dari Ketua Sanksi Dewan. Dalam musyawarah, Dewan Sanksi mempertimbangkan tuduhan INT dan bukti-bukti yang diajukan; argumen responden dan bukti yang diajukan dalam menanggapi tuduhan INT dan bukti-bukti yang ada; jawaban singkat dari INT; presentasi para pihak di persidangan, jika berlaku; dan bahan-bahan lain yang terkandung dalam catatan. Setelah menyelesaikan tinjauannya, Dewan Sanksi menentukan apakah responden yang terlibat dalam dapat dikenakan sanksi atau tidak. Jika demikian, Sanksi Dewan membebankan sanksi pada responden, yang dapat diperpanjang untuk responden afiliasi, penerus dan penerima. Keputusan dari Dewan Sanksi adalah final dan non-diajukan banding. Dengan demikian, Dewan sanksi membebankan sanksi pada responden, yang dapat diperpanjang untuk responden afiliasi, penerus dan penerima. Keputusan dari Dewan Sanksi adalah final dan mengikat. 43

Terkait dengan adanya praktek korupsi, hasil temuan INT dapat dilaporkan kepada otoritas nasional, dalam hal ini kepolisian, kejaksaan atau KPK, untuk dapat dilakukan proses hukum sesuai dengan hukum nasional yang berlaku.

b. Mekanisme Pengawasan IMF

IMF merupakan organisasi moneter dan keuangan antar pemerintah yang hingga saat ini memiliki 189 anggota. ${ }^{4}$ Keanggotaannya terbatas untuk Negara-negara yang bisa mengendalikan hubungan internasionalnya dan mau menerapkan aturanaturan IMF sebagaimana digambarkan dalam instrumen dasar IMF. Sebagaimana ditentukan, IMF memiliki 6 (enam) tujuan, yakni:45

1. Memajukan kerjasama antar anggota dalam mengenai masalah-masalah moneter internasional;

2. Memberi fasilitas bagi perluasan dan pertumbuhan perdagangan internasional yang berimbang dan menyokong perkembangan kapasitas produktif, penciptaan lapangan kerja dan pendapatan riil yang tinggi;

3. Menjaga stabilitas dan pranata system kurs yang tertib serta mempertahankan nilai tukar mata uang yang kompetitif (hard currencies) dari kemerosotan;

4. Membantu sistem pembayaran dan transfer multilateral dan mengupayakan pengurangan pembatasan nilai tukar yang bisa menghambat laju pertumbuhan perdagangan dunia;

5. Menyediakan bantuan keuangan bagi anggota secara temporer dengan pengamanan yang cukup dan memungkinkan koreksi terus-terusan terhadap ketidakseimbangan neraca pembayaran;

6. Mengupayakan penurunan jangka waktu maupun besaran ketidakseimbangan neraca pembayaran.

Aktivitas IMF meliputi pengawasan, bantuan teknis dan bantuan keuangan. Dalam hal pengawasan, IMF harus memantau bekerjanya system moneter internasional dan melakukan pengawasan ketat terhadap kebijakan kurs mata uang anggota-anggotanya. Dua cara pokok yang digunakan IMF untuk menjalankan

terhadap kasus dimulai dari awal lagi. Pengertian Review de novo, Available online from: https://definitions.uslegal.com/d/de-novo-appeal/, (Diakses 10 Agustus 2020)

43 World Bank. (2015). Mekanisme Penjatuhan Sanksi oleh World Bank - Integrity Vice Presidency. Available from: https://www.worldbank.org/en/about/unit/integrity-vice-presidency\#3, (Diakses 10 Agustus 2020)

${ }^{44}$ International Monetary Fund. (2020). IMF Members Quotas and Voting Power, and IMF Board of Governors.

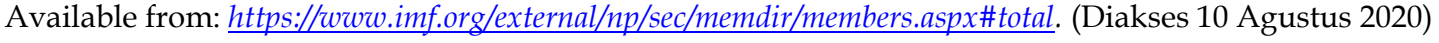

45 Article 1 of the Articles of Agreement of the International Monetary Fund 
fungsinya yaitu melalui konsultasi tahunan dengan Negara-negara anggota dan diskusi tengah tahunan World Economic Outlook serta melakukan pengamatan secara intens kepada Negara-negara yang tidak berutang kepada IMF melalui program bayangan untuk berjaga-berjaga. 46

Mengenai bantuan teknis IMF menyediakan bantuan teknis bagi anggotanya yang mencakup tiga bidang umum yaitu: 1) perancangan dan implementasi kebijakan fiscal dan moneter; 2) pembangunan kelembagaan seperti pengembangan bank sentral, departemen keuangan, kantor pajak, dan bea cukai dan jasa-jasa statistic; 3) dan penyusunan maupun tinjauan mengenai peraturan perundang-undangan yang menyangkut masalah keuangan. Selain itu IMF juga mengadakan pelatihan dan seminar melalui program bantuan teknis di kantor pusat di Washington maupun di kantor Negara perwakilan. 47

System di IMF berbeda dengan World Bank. World Bank memiliki lembaga khusus (integrity vice ministry) untuk mengawasi segala kegiatan yang didanai oleh World Bank, sedangkan IMF tidak memiliki mekanisme pengawasan. Hal ini karena pembiayaan IMF berupa bantuan financial dan asistensi kelembagaan (bantuan teknis) sehingga penggunaan dilakukan secara langsung.

Pengawasan terhadap IMF dilakukan pada saat pra perjanjian utang dengan IMF. Sebagaimana dijelaskan sebelumnya bahwa perjanjian utang luar negeri disahkan melalui undang-undang, dengan demikian, pengawasan utang pemerintah dengan IMF dilakukan oleh lembaga legislatif, dengan mencermati substansi atau materi muatan dalam perjanjian tersebut.

Tidak adanya lembaga integritas memiliki dampak negatif bagi IMF maupun Negara yang didanai. Karena hal ini dapat menimbulkan kesewenang-wenangan oleh lembaga IMF untuk memanfaatkan Negara yang dibantunya untuk merubah kebijakan ekonomi sesuai dengan yang diinginkan oleh IMF. Hal ini dapat menjadi dilema bagi Negara yang dibantu, karena disatu sisi membutuhkan bantuan dari IMF, namun di lain hal tidak dapat menjamin kebijakan yang disarankan oleh IMF akan sesuai dan cocok diterapkan pada Negara tersebut.

Untuk menghindari penyalahgunaan kewenangan tersebut, IMF dapat melakukan beberapa reformasi kelembagaan dari aspek pembuatan keputusan, transparansi, akuntabilitas, partisipasi dan desentralisasi. ${ }^{48}$

1) Pembuatan keputusan kelembagaan

IMF dianggap terlalu banyak membawa kepentingan Amerika Serikat, yang memaksakan pengaruh berlebihan karena memiliki hak suara terbesar. Struktur pengambilan keputusan IMF menjadi problematis, sebagian besar keputusan dibuat berdasarkan consensus, dan diskusi-diskusi Dewan tidak bisa diketahui public. IMF perlu membuat proses pengambilan keputusan yang lebih transparan dan bisa dipertanggungjawabkan. Hasil pemungutan suara dalam Dewan harus dicatat dan bisa dibaca masyarakat.

2) Transparansi

Transparansi informasi IMF harus diperbaiki dengan dua cara: pertama: menambah jenis dokumen yang harus disediakan dan dapat diakses secara luas oleh masyarakat, yang mencakup: konsultasi Artikel IV dan dokumen-

46 Welch, C. (2000). Panduan Mengenai IMF, Jakarta: Invid, h. 50.

47 International Monetary Fund. (2015). Capacity Develpment, Available from: https://www.imf.org/external/np/ins/english/capacity_about.htm, (Diakses 10 Agustus 2020)

48 Welch, C. op cit, h. $85-100$. 
dokumen pendukung lainnya seperti laporan staf (staff report) dan analisis kesimpulan staf (staff concluding report); dokumen-dokumen evaluasi dan audit; Policy Framework Papers (PFPs), Letter of Intent (LoI), dan Memorandum of Understanding (MoU); laporan-laporan manajemen IMF kepada Komite Interim dan Komite Pembangunan; dan ringkasan-ringaksan yang lebih detail dari pertemuan Dewan Eksekutif.

Kedua, sebelum mendapat pertimbangan dewan, IMF dan Pemerintah Negara anggotanya harus mengeluarkan rancangan PSPs, LoI dan matrik-matrik kebijakan sehingga publik dan pemerintah mempunyai kesempatan untuk menanggapi, mengutarakan keberatan atau mengajukan alternatif.

3) Akuntabilitas

IMF harus membuat mekanisme review independent terhadap semua kebijakan program-program dan operasinya untuk memperbaiki akuntabilitas terhadap para pembayar pajak yang mendanainya dan kepada masyarakat yang hidup dibawah program bantuannya. Mekanisme review ini harus permanen sehingga bisa secara konsisten mengevaluasi program-program IMF dan menjamin rekomendasi dari lembaga review tersebut benar-benar dilaksanakan. Lembaga evaluasi harus independen baik secara pendanaan maupun intervensi dari manajement IMF. Untuk meningkatkan akuntabilitas tersebut juga bisa dibentuk kantor pengawas yang ada dalam World Bank dengan World Bank Inspection Panel-nya.

4) Partisipasi

Partisipasi dapat dilakukan dengan dengan cara: pertama, memperluas susunan dewan pengurus yang duduk dalam forum-forum negosiasi. Kedua, melakukan konsolidasi dengan pejabat-pejabat pemerinah dan masyarakat sipil dalam menjalankan fungsi pengawasan regular melalui Resident Representative (RR). Namun partisipasi bisa dibangun dalam setiap tindak lanjut dari pelaksanaan program dan review sesudahnya.

5) Desentralisasi

IMF harus meningkatkan keterbukaannya terhadap ngara-negara debitor dengan cara merancang program di kantor RR, agar tidak tersentalisasi dikantor pusat (Washington DC). IMF setidaknya harus memiliki 70 staff lapangan atau RR di seluruh dunia untuk melaksanakan program-program IMF.

Berdasarkan penjelaskan di atas, maka mekanisme pengawasan utang dari IMF hanya bisa dilakukan pada saat pra perjanjian, atau LoI disahkan oleh pemerintah. Sedangkan untuk melakukan pengawasan terhadap kinerja IMF perlu diadakan reformasi kelembagaan yang menyeluruh terhadap IMF agar dapat berjalan sesuai dengan tujuannya.

\section{Kesimpulan}

Terdapat 3 (tiga) alasan penting pengawasan terhadap penggunaan utang luar negeri sangat diperlukan. Pertama untuk menjamin tidak adanya tendensi politik dari pemberian pinjaman tersebut yang dapat mengintervensi kebijakan Negara. Kedua, memastikan bahwa utang tersebut digunakan sebagaimana mestinya sesuai dengan tujuan dan tepat sasaran. Ketiga untuk menjamin tidak adanya penyelewengan atau praktik-praktik korupsi dalam penggunaan utang luar negeri. 
Konstruksi model pengawasan terhadap penggunaan pinjaman luar negeri dapat dilihat dari aspek internal dan eksternal. Aspek internal berkaitan dengan model pengawasan oleh lembaga pemerintah -sebagai pengguna pinjaman, sedangkan dari aspek eksternal yaitu model pengawasan oleh lembaga pemberi pinjaman internasional (World Bank dan IMF).

Pengawasan internal dilakukan dengan mengacu pada mekanisme kontrol terhadap pembentukan peraturan perundang-undangan. Hal ini mengacu pada pengesahan terhadap perjanjian internasional, dalam hal ini perjanjian utang, dilakukan dengan undang undang. Lembaga negara yang paling berperan dalam hal ini adalah Dewan Perwakilan Rakyat (DPR) sebagai badan legislatif. Selanjutnya mekanisme pengawasan eksternal dalam World Bank dilakukan oleh Integrity Vice Presidency (INT) dan juga terdapat mekanisme sanksi, semetara pada IMF tidak memiliki lembaga pengawasan sebagaimana di World Bank. Oleh karena itu, pengawasan terhadap utang/pinjaman yang berasal dari IMF sangat lemah dan bentumpu pada itikad baik negara peminjam dan mekanisme kontrol yang ada pada negara tersebut

\section{Daftar Pustaka / Daftar Referensi}

\section{Buku}

Hamid, E. S. (2000), Perekonomian Indonesia Masalah dan Kebijakan Kontemporer, Yogyakarta: UII Press

Ibrahim, J. (2008). Teori dan Metodologi Penelitian Hukum Normatif. Malang: Bayu Media.

Lotulung, P. E. (1993). Beberapa Sistem tentang Kontrol Segi Hukum terhadap Pemerintah. Bandung: Citra Aditya Bakti.

Manan, B. (2001). Menyongsong Fajar Otonomi Daerah. Yogyakarta: Pusat Studi Fakultas Hukun UII.

Muchsan. (1992). Sistem Pengawasan terhadap perbuatan Aparat Pemerintah dan Peradilan Tata Usaha Negara di Indonesia. Yogyakarta: Liberty.

Qureshi, A. H. (1999). International Economic Law. Manchaster: Sweet and Maxwell.

Welch, C. (2000). Panduan Mengenai IMF. Jakarta: Invid.

\section{Jurnal}

Atmadja, A. S. (2000). Utang Luar Negeri Pemerintah Indonesia: Perkembangan dan Dampaknya. Jurnal Akuntansi dan Keuangan, 2 (1), 83-94. doi:10.9744/jak.2.1.pp.\%2083-94

Aziz, A. (2011). Analisis Urgensitas Pinjaman Luar Negeri Indonesia dalam Rangka Pembiayaan Defisit APBN. Kajian Ekonomi dan Keuangan, 15 (1), 1-34. DOI: $10.31685 /$ kek.v15i1.78

Bakry, A.B. (2001). Beberapa Aspek Reservasi Dalam Perjanjian Internasional. Perspektif, VI (4), 291-304. DOI: 10.30742/perspektif.v6i4.

Bradshaw, Y. W. \& Huang, J. (2016). Intensifying Global Dependency: Foreign Debt, Structural Adjustment, and Third World Underdevelopment. The Sociological Quarterly, 32 (3). 321-342. doi:10.1111/j.1533-8525.1991.tb00162.x 
Chung, K. (2010). Foreign Debt, Foreign Direct Investment and Volatility. International Economic Journal, 24 (2), 171-196. doi:10.1080/10168731003649628.

Lin, S. \& Sosin, K. (2003). Foreign Debt and Economic Growth. Economics of Transition and Institutional Change, 9 (3), 635-655. doi:10.1111/1468-0351.00092

Odedokun, M. (2004). Multilateral and Bilateral Loans Versus Grants: Issues and Evidence. The World Economy, 27 (2), 239-263. doi:10.1111/j.14679701.2004.00598.x

Pascale, H.D., Ezzeddin, P., \& Swan, C. David. (2016). Suspension and Debarment on the International Stage: Experiences in the World Bank's Sanctions System. Public Procurement Law Review,25 (3). 61-70.

Riyanto, S. (2012). Kedaulatan Negara dalam Kerangka Hukum Internasional Kontemporer, Yustisia Jurnal Hukum, 1 (3), 6-14. DOI: $10.20961 /$ yustisia.v1i3.10074

Sulistyowati, D. \& Suliswanto, M.S.W. (2015). Pertumbuhan Ekonomi, Indeks Pembangunan Manusia, Utang Luar Negeri dan Kemiskinan (Kajian Teoritis di Indonesia). Journal of Innovation in Business and Economics, 6 (1), 89-106. DOI: 10.22219 /jibe.v6i1.2276.

Wuisang, A. (2019). Kewenangan DPR Dalam Ratifikasi Perjanjian Internasional Pasca Terbitnya Putusan Mahkamah Konstitusi No. 13/PUU-XVI/2018. Pakuan Law Review, 5 (2), 121-145. DOI: 10.33751/.v5i2.1189.

\section{Artikel dari Sumber Online}

Laucereno, S.F. (2018). Utang Luar Negeri RI Naik Jadi Rp 5.127 Triliun. Retrieve from:

https:/ / finance.detik.com/moneter/d-4118091/utang-luar-negeri-ri-naik-jadirp-5127-triliun, diakses 6 Juli 2020

Adventa, E. (2017). Utang Jatuh Tempo RI di 2018-2019 Mencapai Rp 810 Triliun. Retrieve from:

https://ekonomi.kompas.com/read/2017/07/04/110000426/utang.jatuh.te mpo.ri.di.2018-2019.mencapai.rp.810.triliun. Diakses 6 Juli 2020

Fauzia, M. (2020). Hingga April 2020, Utang Pemerintah Capai Rp. 5.172,48 Triliun. Retrieve from: dari:

https://money.kompas.com/read/2020/05/21/081100326/hingga-april2020-utang-pemerintah-capai-rp-5.172-48-triliun. Diakses 6 Juli 2020

Profil Utang Pemerintah Pusat, Pinjaman dan Surat Berharga Negara. (2015). Kementerian Keuangan Republik Indonesia Direktorat Jendral Pengelolaan Pembiayaan dan Resiko. Retrieve from: https://www.djppr.kemenkeu.go.id/uploads/files/dmodata/BSPUPP\%20( Govt\%20Debt\%20Profile)\%20edisi\%20Des\%202015.pdf. Dikases 6 Juli 2020

Bank Dunia Memberikan Sanksi Kepada Penerbit Indonesia dalam Proyek Pengembangan Buku dan Bacaan. (2009). Retrieve from: https://materikuliahfhunibraw.files.wordpress.com/2009/09/bank-duniamemberikan-sanksi-kepada-penerbit-indonesia-dalam-proyekpengembangan-buku-dan-bacaan.pdf. Diakses 6 Juli 2020

Mekanisme Penjatuhan Sanksi oleh World Bank - Integrity Vice Presidency. (2020). Retrieve from: https://www.worldbank.org/en/about/unit/integrity-vice-presidency\#3. Diakses 10 Agustus 2020 
IMF Members Quotas and Voting Power, and IMF Board of Governors. (2020). Retrieve from:

https://www.imf.org/external/np/sec/memdir/members.aspx\#total. Diakses 6 Juli 2020

International Monetary Fund, Capacity Develpment. (2020). Retrieve from: https://www.imf.org/external/np/ins/english/capacity_about.htm, Diakses 10 Agustus 2020

Pengertian Review de novo, (2020) Retrieve from: https://definitions.uslegal.com/d/de-novo-appeal/, Diakses 6 Juli 2020

The World Bank. Integrity Vice Presidency. Retrieve from: https://www.worldbank.org/en/about/unit/integrity-vicepresidency, Diakses 22 Agustus 2020

The World Bank. World Bank Group Sanction Board. Retrieve from https://www.worldbank.org/en/about/unit/sanctions-system/sanctionsboard, Diakses 22 Agustus 2020

The World Bank. (2006). World Bank Launches Voluntary Disclosure Program. Retrieve from https://www.worldbank.org/en/news/pressrelease/2006/08/15/world-bank-launches-voluntary-disclosure-program, Diakses 22 Agustus 2020

\section{Peraturan Perundangan-Undangan}

Undang Undang Republik Indonesia Nomor 24 Tahun 2000 tentang Perjanjian Internasional

Undang-Undang Republik Indonesia Nomor 12 Tahun 2011 Tentang

Pembentukan Peraturan Perundang-Undangan

Peraturan Pemerintah Republik Indonesia Nomor 10 Tahun 2011 tentang Tata

Cara Pengadaan Pinjaman Luar Negeri dan Penerimaan Hibah.

\section{Instrumen Internasional}

Article of Agreement of International Bank for Reconstruction and Development. Article of Agreement of International Monetary Fund. 